\title{
On the interactions between mesenchymal stem cells and regulatory $T$ cells for immunomodulation in transplantation
}

\section{Anja U. Engela ${ }^{1}$, Carla C. Baan ${ }^{1}$, Frank J. M. F. Dor ${ }^{2}$, Willem Weimar ${ }^{1}$ and Martin J. Hoogduijn ${ }^{1 *}$}

${ }_{1}^{1}$ Transplantation Laboratory, Department of Internal Medicine, Erasmus MC, University Medical Center, Rotterdam, Netherlands

${ }^{2}$ Department of Surgery, Erasmus MC, University Medical Center, Rotterdam, Netherlands

\section{Edited by:}

Yair Reisner, Weizmann Institute of

Science, Israel

\section{Reviewed by:}

Myra Coppage, University of

Rochester Medical Center, USA

Reem Al-Daccak, Institut National de

la Santé et de la Recherche Médicale,

France

\section{${ }^{*}$ Correspondence:}

Martin J. Hoogduijn, Transplantation Laboratory, Department of Internal Medicine, Erasmus MC, University Medical Center, PO Box 2040, 3000 CA Rotterdam, Netherlands. e-mail: m.hoogduijn@erasmusmc.nl
Experimental studies have established the use of mesenchymal stem cells (MSC) as a candidate immunosuppressive therapy. MSC exert their immunomodulatory function through the inhibition of $\mathrm{CD}^{+}$and $\mathrm{CD}^{+} \mathrm{T}$ cell proliferation. It is unknown whether MSC impair the immunosuppressive function of regulatory T cells (Treg). In vitro and in vivo studies suggest that MSC mediate their immunomodulatory effects through the induction of Treg. In this review we will focus on the interactions between MSC and Treg, and evaluate the consequences of these cellular interplays for prospective MSC immunotherapy in organ transplantation.

\section{Keywords: mesenchymal stem cell, regulatory $\mathrm{T}$ cell, transplantation}

\section{INTRODUCTION TO MSC AND TREG}

Since the discovery of mesenchymal stem cells (MSC) in bone marrow by Friedenstein etal. (1970), researchers were able to isolate these adherent cells from various postnatal and adult tissue sources (Pittenger etal., 1999; Zuk etal., 2002; Hoogduijn et al., 2007; Antonucci et al., 2011). MSC are self-renewing and capable of forming colonies while retaining their multilineage differentiation potential. They are able to differentiate into adipocytes, chondrocytes, osteoblasts, and myocytes (Pittenger et al., 1999; de la Garza-Rodea et al., 2012). These features represent part of the criteria that define MSC (Dominici et al., 2006). MSC are immunophenotypically characterized by the expression of the cell surface markers CD73, CD90, CD105, and HLA-DR ${ }^{\text {low }}$, and the absence of CD11b, CD14, CD19, CD34, CD45, and CD79 $\alpha$. Interest in MSC for their use in transplantation was fostered when it was first discovered that MSC possess $\mathrm{T}$ cell suppressive properties (Bartholomew et al., 2002). Intensive research was undertaken to unravel the mechanisms by which MSC exert their immunomodulatory functions. Besides CD $4^{+}$ helper $\mathrm{T}$ cells and $\mathrm{CD}^{+}$cytotoxic $\mathrm{T}$ cells, activated $\mathrm{B}$ cells and natural killer (NK) cells are also susceptible to the suppressive activity of MSC (Corcione etal., 2006; Sotiropoulou etal., 2006). Further, MSC hamper the maturation of dendritic cells (DC) through the downregulation of MHC class II molecules and co-stimulatory molecules (Aggarwal and Pittenger, 2005; Jiang et al., 2005; Nauta et al., 2006). In addition to these immunosuppressive effects, MSC also have immunosupportive properties; they delay the apoptosis of neutrophils, preserving them to be readily available to counter infections (Raffaghello et al., 2008). Immunomodulation by MSC is mediated by cell-cell contact and the release of soluble factors. Important mediators are indoleamine 2,3-dioxygenase (IDO), transforming growth factorbeta (TGF- $\beta$ ), interleukin-10 (IL-10), prostaglandin E2 (PGE2), hepatocyte growth factor (HGF), human leukocyte antigen-G5 (HLA-G5), and nitric oxide (NO; Di Nicola et al., 2002; Meisel et al., 2004; Groh etal., 2005; Batten etal., 2006; Nasef etal., 2007; Sato etal., 2007; Hoogduijn etal., 2010a; Deuse etal., 2011). The ability of MSC to exert their immunosuppressive function requires MSC activation in a pro-inflammatory microenvironment through the presence of cytokines like interferongamma (IFN- $\gamma$ ), tumor necrosis factor-alpha (TNF- $\alpha$ ), IL- $1 \alpha$, and IL-1 $\beta$ (Crop et al., 2010). Collecting in vivo data suggest that MSC could be used as immunotherapy (Bartholomew et al., 2002; Popp et al., 2008). In clinical studies MSC have successfully attenuated graft-versus-host-disease (GvHD) after hematopoietic stem cell transplantation (Le Blanc et al., 2004, 2008). Currently, research groups strive to confirm the safety and feasibility of MSC therapy in solid organ transplantation (Hoogduijn et al., 2010b; Perico et al., 2011).

Primarily $\mathrm{T}$ cells are targeted by the immunosuppressive effect of MSC which raises the question, to what extent MSC affect $\mathrm{T}$ cells with immunomodulatory properties. Regulatory T cells (Treg) were first characterized by Sakaguchi et al. (1995) as activated $\mathrm{CD}^{+} \mathrm{T}$ cells expressing $\mathrm{CD} 25$, the IL-2 receptor alpha-chain, which are involved in the maintenance of tolerance to self-antigens. Human Treg are commonly characterized by their expression of the transcription factor forkhead box P3 (FOXP3) and the FOXP3 reciprocal expression of CD127, the IL-7 receptor alpha-chain (Fontenot et al., 2003; Liu et al., 2006; Seddiki et al., 2006); additional markers are the co-stimulatory 
molecules cytotoxic T lymphocyte antigen-4 (CTLA-4) and the glucocorticoid-induced TNF receptor-related protein (GITR; Read etal., 2000; Salomon etal., 2000; Takahashi etal., 2000; McHugh et al., 2002; Shimizu et al., 2002). While a unique marker for human Treg is yet to be identified, FOXP3 presents a reliable marker for Treg in mice (Ziegler, 2006).

The importance of Treg in the maintenance of tolerance is highlighted in humans suffering from immunodysregulation polyendocrinopathy enteropathy X-linked syndrome (IPEX; Bennett et al., 2001; Kobayashi et al., 2001). IPEX patients lack functional Treg as a result of a point mutation in the Foxp3 gene (Bacchetta et al., 2006). In other autoimmune diseases, the role of Treg remains controversial (Buckner, 2010). The immunomodulating nature of Treg made them interesting candidates for the induction of transplantation tolerance. Indeed, Treg have been reported to control alloreactivity by inhibiting the functionality of cell types similar to those suppressed by MSC; Treg hamper the proliferation of $\mathrm{CD}^{+} \mathrm{T}$ cells, $\mathrm{CD}^{+} \mathrm{T}$ cells, and $\mathrm{DC}$ (Velthuis et al., 2006; Bestard etal., 2007; Tang and Bluestone, 2008; Hendrikx et al., 2009a). Further, molecules associated with the tolerogenic and suppressive function of Treg partially overlap with those involved in MSC-mediated immunomodulation and include IL-10, TGF- $\beta$, and heme oxygenase-1 (HO-1; Tang and Bluestone, 2008). In addition, it has been hypothesized that Treg are able to influence their target cells in a granzyme B-dependent and perforin-dependent manner (Grossman et al., 2004; Gondek et al., 2005). Results from different humanized mouse models and clinical studies in patients with GvHD encourage the use of freshly isolated or ex vivo expanded Treg (Trzonkowski et al., 2009; Issa et al., 2010; Nadig et al., 2010; Brunstein et al., 2011; Di Ianni etal., 2011). Despite the indication that Treg therapy is promising and well tolerated in patients receiving stem cell treatment, clinical information about the application of Treg in solid organ transplantation is still lacking. However, Treg represent one of the immunomodulatory cell types whose clinical safety is currently under investigation (McMurchy et al., 2011; Schliesser et al., 2012).

Both MSC and Treg are able to influence the adaptive immune system by utilizing similar and distinct mechanisms. Therefore, it is of interest whether the overlapping mechanisms cause interference of the immunomodulatory properties of both cell types.

\section{IN VITRO INTERACTION BETWEEN MSC AND TREG}

Recently we investigated the interaction between MSC and Treg in a transplantation setting (Engela et al., 2012). We found that MSC derived from healthy kidney donors permitted the function of Treg from healthy donors as well as Treg from renal transplant patients. Vice versa, Treg did not hamper MSC function.

One of the first indications that $\mathrm{T}$ cells with a regulatory phenotype are unaffected by the suppressive capacities of MSC was provided by Maccario etal. (2005). This group reported that although autologous MSC and third-party MSC were able to suppress the proliferation of $\mathrm{CD}^{+} \mathrm{T}$ cells and $\mathrm{CD} 8^{+} \mathrm{T}$ cells in primary mixed lymphocyte cultures (MLC), after restimulation in secondary MLC the numbers of $\mathrm{CD}^{+} \mathrm{T}$ cells co-expressing CD25 and/or CTLA-4 increased. This indicates an MSC-dependent preferential differentiation into $\mathrm{T}$ cells with a regulatory phenotype. Similar observations were made by Prevosto et al. (2007) after PBMC-MSC co-culture. In addition, IL-2 stimulation of PBMC in the presence of MSC also led to elevated proportions of $\mathrm{CD} 4{ }^{+} \mathrm{CD} 25^{+}$cells (Aggarwal and Pittenger, 2005). It has to be considered that due to lack of appropriate markers no distinction could be made between activated effector cells and Treg in these early research studies. Employing newly discovered markers, Di Ianni et al. (2008) performed an extensive study to shed light on the $\mathrm{T}$ cell population that is most responsive to the MSC-stimulus for Treg generation. The largest numbers of $\mathrm{CD} 4^{+} \mathrm{CD} 25^{+} \mathrm{FOXP}^{+} \mathrm{CD} 127^{-}$ Treg were found when MSC were cultured with immunoselected $\mathrm{CD}^{+}{ }^{+} \mathrm{CD}_{4} 5 \mathrm{RA}^{+}$or $\mathrm{CD} 3{ }^{+} \mathrm{CD} 45 \mathrm{RO}^{+}$fractions. Co-culture of MSC with different Treg populations such as $\mathrm{CD} 4^{+} \mathrm{CD} 25^{+}$ cells, $\mathrm{CD} 4{ }^{+} \mathrm{CD} 25^{+} \mathrm{CD} 45 \mathrm{RA}{ }^{+}$cells, and $\mathrm{CD} 4{ }^{+} \mathrm{CD} 25^{+} \mathrm{CD} 45 \mathrm{RO}^{+}$ cells maintained FOXP3 expression, CD127 downregulation, and the immunosuppressive activities of Treg for about 2 weeks. In the absence of MSC the Treg populations lost their suppressive capacities during this period.

The apparent interplay between MSC and Treg in the allosuppression of $\mathrm{T}$ cell proliferation triggered researchers' interest in the factors and mediators involved. Although conflicting data exist, it is the current opinion that key factors involved in Treg induction by MSC are MSC-derived TGF- $\beta$ and PGE2 (Prevosto et al., 2007; English et al., 2009). TGF- $\beta$ is a key regulator of the initiation and maintenance of FOXP3 expression, and the suppressive function of Treg (Chen et al., 2003; Fu et al., 2004). PGE2 is an immunosuppressant that inhibits $\mathrm{T}$ cell mitogenesis and the production of IL-2. TGF- $\beta$ and PGE2 are constitutively produced by MSC. Secretion of these two immunomodulatory molecules can be increased through "MSC licensing," the activation of MSC with TNF- $\alpha$ and IFN- $\gamma$ which improves their immunosuppressive capacity (English etal., 2007; Ryan etal., 2007). MSC-derived PGE2 also exerts suppressive functions by increasing the IL-10 production of macrophages and by limiting monocyte differentiation into DC (Nemeth etal., 2009; Spaggiari et al., 2009). It has also been reported that PGE2 induces a regulatory phenotype in $\mathrm{CD} 4^{+} \mathrm{CD} 25^{-} \mathrm{T}$ cells by modulating the expression of FOXP3 and therefore contributes to Treg function (Baratelli et al., 2005). In addition, cell-cell contact seems to play a non-redundant role in the induction of Treg (English et al., 2009). After culture of $\mathrm{CD} 4^{+}$cells with MSC, increases in mRNA levels of CD25 and FOXP3 mRNA were only detected when cells were in close proximity; when cells were separated by a tissue culture insert, this effect was not observed. For enhancement of FOXP3 expression in PBMC, however, direct MSC-PBMC contact was not required. This suggests that cellcell contact between certain PBMC subpopulations contributes to the FOXP3 expression and substitutes for $\mathrm{MSC}-\mathrm{CD} 4^{+}$cell contact interactions. Another factor influencing the immunomodulatory effect of MSC on alloactivated T cells as well as the expansion of $\mathrm{CD}^{+}{ }^{+} \mathrm{CD} 25^{+} \mathrm{FOXP}^{+}$Treg is the soluble protein HLA-G5 (Selmani etal., 2008). In the presence of anti-HLAG5 antibody, MSC-mediated immunosuppression was hampered. Neutralization of the HLA-G5 protein led to a decrease in the generation of $\mathrm{CD}^{+}{ }^{+} \mathrm{CD} 25^{+} \mathrm{FOXP}^{+}{ }^{+} \mathrm{T}$ cells. In addition, the 
tryptophan-catabolizing enzyme IDO was identified as a crucial modulator of the immunosuppressive effect of MSC (Meisel et al., 2004; Jurgens et al., 2009). Using a renal allograft model, Ge et al. (2010) investigated whether MSC-driven T cell suppression is also a consequence of the induction of Treg. Graft survival in untreated kidney recipients was significantly lower than graft survival in mice after MSC treatment. Increased serum levels of kynurenine in MSC-treated allograft recipients indicated increased IDO enzymatic activity and correlated with higher frequencies of $\mathrm{CD}^{+}{ }^{+} \mathrm{CD} 25^{+} \mathrm{FOXP}^{+}$Treg in recipient spleen and in the allograft. In this model recipient treatment with IDO-knockout MSC or the IDO inhibitor 1-methyl-tryptophan did not achieve graft tolerance. Therefore, the expression of functional IDO seems to be a prerequisite for MSC-mediated graft acceptance via direct $\mathrm{T}$ cell suppression as well as indirect modulation of the graft recipient's immune system through Treg induction. Skewing of $\mathrm{CD}^{+}{ }^{+} \mathrm{T}$ cell differentiation toward a more regulatory phenotype leads to the inhibition of T helper 17 (Th17) cell differentiation, an effect which is partly caused by MSC-derived IDO and PGE2 (Ghannam et al., 2010; Tatara et al., 2011). The role of IL-17, produced by Th17 cells, in the onset of GvHD is still controversial. Disease-ameliorating effects and an inductive role of ex vivo differentiated Th17 cells have been reported (Carlson et al., 2009; Kappel et al., 2009).

In summary, the mechanisms employed by MSC to inhibit effector $\mathrm{T}$ cell proliferation overlap with the mechanisms involved in Treg induction, yet, they do not interfere with Treg function.

\section{IN VIVO INTERACTION BETWEEN MSC AND TREG}

Whether MSC-mediated in vitro induction of Treg can be translated into the in vivo setting or even into the clinical setting remains to be thoroughly investigated. To date little evidence from animal models exists. One of the first in vivo studies, reporting the induction of Treg after MSC administration, was conducted by Gonzalez et al. (2009). Mice suffering from induced colitis were treated with a systemic infusion of human MSC. MSC ameliorated the severity of colitis through the reduction of inflammatory cytokines and chemokines and an increase of IL-10 concentrations; an overall downregulation of Th1-driven autoimmune responses and inflammatory responses was observed. Although MSC infusion impaired the expansion of Th1 cells, functional $\mathrm{CD} 4{ }^{+} \mathrm{CD} 25^{+} \mathrm{FOXP}_{3}{ }^{+}$Treg were induced, confirming the in vitro MSC-Treg interplay.

A similar observation was recently made in a mouse model of allergen-driven airway inflammation (Kavanagh and Mahon, 2011). Systemic administration of allogeneic mouse MSC reduced the classical pathologies in this model as airway-mucus secretion, allergen-driven lung eosinophilia, and IgE induction were diminished. The improved pathological outcome coincided with a higher percentage of $\mathrm{CD}^{+}{ }^{+} \mathrm{FOXP} 3^{+}$cells in both lungs and spleens of MSC-treated mice when compared to control mice. Kavanagh and Mahon (2011) demonstrated the importance of Treg induction by MSC in this model; after in vivo depletion of Treg with cyclophosphamide an amelioration of the disease pathologies was observed, which serves as further evidence that the capability of MSC therapy to induce Treg is essential for this therapeutic modality.
In transplantation, one of the first models demonstrating the in vivo induction of Treg after MSC administration was described by Casiraghi etal. (2008). In a semi-allogeneic heart transplant mouse model, pre-transplant infusion of donor-derived MSC into the portal vein led to $\mathrm{T}$ cell hyporesponsiveness, prolonged cardiac allograft survival and expanded donor-specific Treg expressing CD4, CD25, and FOXP3. Similar observations were made after administration of recipient-derived MSC. Of relevance for the translation into a clinical setting, this group noticed that double pre-transplant infusions were more tolerogenically effective than a single MSC infusion. In contrast, post-transplant infusion of MSC was not effective. This suggests that pre-exposure to donor-MSC is required or that pre-activation of MSC might be necessary for MSC to successfully exert their tolerogenic action when graft alloantigens challenge the recipient's immune system.

Further evidence that the generation of Treg by MSC contributes to graft survival is provided by a kidney allograft mouse model (Ge et al., 2010). In contrast to the findings by Casiraghi et al. (2008), in this model intravenous administration of MSC $24 \mathrm{~h}$ after renal transplantation inhibited $\mathrm{T}$ cell proliferation. In tolerant recipients a Th2-dominant cytokine shift was observed as a significant decrease of IFN- $\gamma$ production was detected while IL4 levels were significantly increased. Further, in recipient spleens, frequencies of $\mathrm{CD}^{+}{ }^{+} \mathrm{CD} 25^{+} \mathrm{FOXP} 3^{+} \mathrm{T}$ cells were higher in MSCtreated mice. Ge et al. (2010) also found a significant increase of intragraft $\mathrm{FOXP}^{+}$cells after MSC treatment suggesting Treg recruitment to the renal allograft. In this model, depletion of Treg using an anti-CD25 monoclonal antibody also reversed the beneficial effect of MSC therapy. CD25 ${ }^{+} \mathrm{T}$ cell depletion caused graft rejection despite MSC treatment. This study again emphasized the importance of IDO as a mediator of MSC function. MSC derived from IDO-knockout mice were not able to induce graft tolerance. In a similar fashion, in vivo inhibition of IDO also abrogated the tolerogenic effect of MSC revealing a significant role of IDO in MSC immunosuppressivity.

\section{INTERACTION BETWEEN MSC AND TREG IN THE CLINICAL SETTING}

Results from preclinical studies support the plethora of in vitro data and confirm that MSC-mediated induction of Treg has functional relevance in vivo. Nevertheless, to date only one clinical study looked into this aspect of MSC therapy in a transplantation setting (Perico et al., 2011). In this safety and clinical feasibility study, autologous MSC were administered intravenously to two patients 7 days after they received living-related kidney grafts. Despite a concerning increase in serum-creatine levels after MSC infusion, stable graft function was reported for both patients 1 year after transplantation. Both patients received induction therapy in combination with standard maintenance immunosuppression. The induction regimen consisting of basiliximab and low-dose rabbit anti-thymocyte globulin (rATG) caused a profound depletion of $\mathrm{CD}^{+}$and $\mathrm{CD}^{+}{ }^{+} \mathrm{T}$ cells in the peripheral blood in MSC-treated and non-MSC treated patients during the first 30 days. In patients with MSC therapy the number of CD4 ${ }^{+}$ $\mathrm{T}$ cells remained lower during the entire follow-up time when compared to the number of $\mathrm{CD} 4^{+} \mathrm{T}$ cells in non-MSC patients. 
In contrast, $\mathrm{CD}^{+} \mathrm{T}$ cell repopulation to pre-transplant levels was achieved in both patient groups. During $\mathrm{T}$ cell depletion, the percentage of $\mathrm{CD} 4^{+} \mathrm{CD} 25^{+} \mathrm{FOXP} 3^{+} \mathrm{CD} 127^{-}$Treg within the total $\mathrm{CD} 4^{+} \mathrm{T}$ cell population was reduced. However, after 30 days the percentage of Treg increased in both MSC-treated patients. The memory $\mathrm{CD}^{+}{ }^{+} \mathrm{CD} 45 \mathrm{RO}^{+} \mathrm{RA}^{-} \mathrm{T}$ cells in both MSC-treated patients remained lower than pre-transplant levels after 30 days post-transplant despite the full recovery of total $\mathrm{CD}^{+} \mathrm{T}$ cell counts around this time-point. This effect was less prominent in patients who did not receive MSC. These findings indicate that in comparison to the immunosuppressive medication MSC might have an additional inhibitory effect on memory $\mathrm{CD}^{+} \mathrm{T}$ cell proliferation. The combination of reduced memory $\mathrm{CD}^{+} \mathrm{T}$ cells and increased percentages of Treg suggests that MSC treatment leads to a more pro-tolerogenic environment. Yet, it cannot entirely be ruled out that the observed effects are due to the MSC treatment and not evoked by the rATG induction therapy. More clinical experience with MSC therapy is required to obtain confident data.

\section{INTERACTION OF MSC AND TREG WITH IMMUNOSUPPRESSIVE MEDICATION}

Achieving graft tolerance, the long-term goal in transplantation immunology, is a major challenge. Controlling the immune response to donor-antigen in the graft recipient is currently accomplished by the administration of immunosuppressive drugs. Upon the introduction of novel cellular immunotherapies they will be applied in combination with standard immunosuppressive regimens. It therefore has to be considered that these drugs may not be permissive for MSC and/or Treg function. Conversely, MSC and Treg may interfere with the efficacy of the agents.

In vitro studies show that MSC reduce the efficacy of rapamycin and tacrolimus and, conversely, that these immunomodulatory agents negatively affect MSC function (Hoogduijn et al., 2008; Buron et al., 2009). However, cumulative inhibition of effector cell proliferation has been reported for combination therapy of MSC with mycophenolic acid (MPA) while dexamethasone did not influence MSC functionality. A synergistic effect of MSC and mycophenolate mofetil (MMF), the prodrug of MPA, on prolonged graft survival was observed in a fully allogeneic heart transplant mouse model (Eggenhofer et al., 2011); treatment with MSC and cyclosporine A failed to prolong allograft survival. In contrast to in vitro results, combination therapy of MSC and rapamycin achieved long-term heart allograft tolerance in mice and increased the frequency of splenic $\mathrm{CD} 4^{+} \mathrm{CD} 25^{+} \mathrm{FOXP}^{+} \mathrm{T}$ cells (Ge etal., 2009). This finding is important as rapamycin is currently used for the ex vivo expansion of Treg (Battaglia et al., 2012). In renal transplant patients rapamycin led to an increase of CD4 ${ }^{+} \mathrm{CD} 25^{+} \mathrm{FOXP}^{+}{ }^{+}$Treg (Hendrikx et al., 2009b). A recent study by $\mathrm{Ma}$ etal. (2011) indicated that in vitro rapamycin had better synergistic effects on Treg function than cyclosporine A and tacrolimus. Subsequent adoptive infusion of donor-alloantigen-specific Treg in combination with low-dose of rapamycin delayed the acute rejection of kidney allografts in Cynomolgus monkeys. In addition, selective expansion of donortype $\mathrm{CD}^{+}{ }^{+} \mathrm{CD} 25^{+} \mathrm{FOXP}^{+}$Treg after in vivo administration of rapamycin in combination with IL-2 suppressed acute GvHD in mice (Shin et al., 2011).

The interactions between both immunomodulatory cell types and immunosuppressive drugs demonstrate that the choice of immunosuppressive regimen will affect the outcome of cellular therapies.

\section{HETEROGENEITY OF THE TREG POPULATION}

Recent developments in Treg research revealed a heterogeneity of the Treg population. Apart from the well-described thymicderived naturally occurring $\mathrm{CD} 4{ }^{+} \mathrm{CD} 25^{+} \mathrm{CD} 127-\mathrm{FOXP} 3{ }^{+}$Treg (nTreg), other Treg subsets have been identified. Of these the most studied are induced Treg (iTreg). iTreg develop from naïve T cells in the periphery and their induction occurs upon T cell receptor stimulation, CD28 co-stimulatory signaling, and in the presence of IL-2 and TGF- $\beta$. Phenotypically iTreg resemble nTreg, yet, both populations can be distinguished by the methylation status of a special locus within the Foxp3 gene (Baron et al., 2007; Wieczorek et al., 2009). In nTreg this locus, the Treg-specific-demethylated-region (TSDR), is fully demethylated allowing for easy transcription while the TSDR in iTreg is methylated. Further discrimination between nTreg and iTreg may be provided by Helios, an Icaros family transcription factor. It has been reported that nTreg express Helios while iTreg do not (Thornton et al., 2010). Opinion on this topic is divided, some groups claim that Helios only presents an additional activation marker and is mutually expressed by natural Treg and induced Treg (Akimova et al., 2011; Gottschalk et al., 2012).

Apart from these two Treg subsets, non-FOXP3 expressing $\mathrm{CD}^{+}{ }^{+}$Treg have been described such as the IL-10 expressing $\mathrm{T}$ regulatory (Tr) 1 cells and TGF- $\beta$ expressing Th3 cells (Weiner, 2001; Roncarolo etal., 2006). Other $\mathrm{T}$ cells with regulatory functions have been studied, but less extensively (Hayday and Tigelaar, 2003; Reibke et al., 2006; Ford McIntyre et al., 2008; Monteiro et al., 2010).

These new findings have to be considered when previous Treg work is evaluated. Further research will be required to investigate and to distinguish the influence of MSC on Treg expansion and Treg induction.

\section{THE IMPORTANCE OF TREG INDUCTION BY MSC}

The fate of MSC in the body after administration has been revealed by multiple distribution studies (Barbash et al., 2003; Kraitchman et al., 2005; Fischer et al., 2009; Assis et al., 2010; Zonta et al., 2010). Using various types of tracking techniques it was determined that MSC accumulate in the lung after intravenous infusion. The size of cultured MSC is significantly larger than the size of other immune cells in the circulation. This might cause MSC to be trapped in the capillaries of the lung. When MSC were administered via alternative routes, they were also found in other organs such as liver and spleen (Shi et al., 2010). Despite the consistency of the data, the drawback of these studies is that researchers cannot be certain that label detection confirms the presence of living MSC. Retrieved label can originate from viable MSC, deceased MSC or possibly phagocytosed debris of MSC.

To gain more clarity on this issue, different approaches have been examined (Hoogduijn et al., 2011). After intravenous 
administration of labeled MSC to mice, organs were harvested, and MSC were isolated and re-cultured. Interestingly, labeled MSC were found in the lung up to $24 \mathrm{~h}$ after infusion, but in none of the other observed organs at any time after administration.

The apparent shortevity of MSC after infusion fortifies the importance of rapid Treg induction by MSC. While MSC are retained in different tissues shortly after administration and subsequently cleared, they "transfer" their immunomodulatory effect to other immunosuppressive mediators. Hence, when infused MSC are not present any longer to execute their suppressive functions, increased numbers of Treg are available to enforce graft acceptance.

\section{CONCLUSION}

Although currently prescribed drug-based immunosuppressive regimen are effective in preventing graft rejection in transplant patients, their main shortcoming is that their long-term application causes malignancies, infections, and nephrotoxicity. Due to their immunomodulatory capabilities, MSC have a high potential

\section{REFERENCES}

Aggarwal, S., and Pittenger, M. F. (2005). Human mesenchymal stem cells modulate allogeneic immune cell responses. Blood 105, 1815-1822.

Akimova, T., Beier, U. H., Wang, L., Levine, M. H., and Hancock, W. W. (2011). Helios expression is a marker of $\mathrm{T}$ cell activation and proliferation. PLoS ONE 6, e24226. doi: 10.1371/journal.pone.0024226

Antonucci, I., Stuppia, L., Kaneko, Y., Yu, S., Tajiri, N., Bae, E. C., Chheda, S. H., Weinbren, N. L., and Borlongan, C. V. (2011). Amniotic fluid as a rich source of mesenchymal stromal cells for transplantation therapy. Cell Transplant. 20, 789-795.

Assis, A. C., Carvalho, J. L., Jacoby, B. A., Ferreira, R. L., Castanheira, P., Diniz, S. O., Cardoso, V. N., Goes, A. M., and Ferreira, A. J. (2010). Timedependent migration of systemically delivered bone marrow mesenchymal stem cells to the infarcted heart. Cell Transplant. 19, 219-230.

Bacchetta, R., Passerini, L., Gambineri, E., Dai, M., Allan, S. E., Perroni, L., Dagna-Bricarelli, F., Sartirana, C., Matthes-Martin, S., Lawitschka, A., Azzari, C., Ziegler, S. F., Levings, M. K., and Roncarolo, M. G. (2006). Defective regulatory and effector $\mathrm{T}$ cell functions in patients with FOXP3 mutations. J. Clin. Invest. 116, 1713-1722.

Baratelli, F., Lin, Y., Zhu, L., Yang, S. C., Heuze-Vourc'h, N., Zeng, G., Reckamp, K., Dohadwala, M., Sharma, S., and Dubinett, S. M. (2005). Prostaglandin E2 induces FOXP3 gene expression and $\mathrm{T}$ regulatory cell function in human $\mathrm{CD}^{+}$ T cells. J. Immunol. 175, 1483-1490.
Barbash, I. M., Chouraqui, P., Baron, J., Feinberg, M. S., Etzion, S., Tessone, A., Miller, L., Guetta, E., Zipori, D., Kedes, L. H., Kloner, R. A., and Leor, J. (2003). Systemic delivery of bone marrow-derived mesenchymal stem cells to the infarcted myocardium: feasibility, cell migration, and body distribution. Circulation 108, 863-868.

Baron, U., Floess, S., Wieczorek, G., Baumann, K., Grutzkau, A., Dong, J., Thiel, A., Boeld, T. J., Hoffmann, P., Edinger, M., Turbachova, I., Hamann, A., Olek, S., and Huehn, J. (2007). DNA demethylation in the human FOXP3 locus discriminates regulatory $\mathrm{T}$ cells from activated FOXP3 (+) conventional T cells. Eur. J. Immunol. 37, 2378-2389.

Bartholomew, A., Sturgeon, C., Siatskas, M., Ferrer, K., McIntosh, K., Patil, S., Hardy, W., Devine, S., Ucker, D., Deans, R., Moseley, A., and Hoffman, R. (2002). Mesenchymal stem cells suppress lymphocyte proliferation in vitro and prolong skin graft survival in vivo. Exp. Hematol. 30, 42-48.

Battaglia, M., Stabilini, A., and Tresoldi, E. (2012). Expanding human T regulatory cells with the mTOR-inhibitor rapamycin. Methods Mol. Biol. 821, 279-293.

Batten, P., Sarathchandra, P., Antoniw, J. W., Tay, S. S., Lowdell, M. W., Taylor, P. M., and Yacoub, M. H. (2006). Human mesenchymal stem cells induce $\mathrm{T}$ cell anergy and downregulate $\mathrm{T}$ cell allo-responses via the TH2 pathway: relevance to tissue engineering human heart valves. Tissue Eng. 12, 2263-2273.

Bennett, C. L., Christie, J., Ramsdell, F., Brunkow, M. E., Ferguson, P. J.,

to function as alternative immunosuppressive therapy possibly with less side effects. While drugs mainly target a specific molecular pathway to achieve immunomodulation, MSC appear to have a broader effect on the patient's immune system. Yet, further characterization of this more global intervention by MSC is required. Despite inflicting their immunosuppressive effect on most lymphocyte subsets including T cells, MSC spare Treg. In fact, preclinical and clinical studies indicate that MSC mediate the expansion of natural Treg and/or the induction of novel Treg. This becomes an important feature of MSC immunomodulation as MSC appear to be cleared by the recipient's immune system shortly after infusion and hence will not be able to perform their suppressive capacities via direct cell-cell contact or soluble factors. Because of the multifaceted mechanisms by which MSC apply their immunosuppressivity combined with the fact that they do not impair the functionality of host Treg, MSC are very interesting candidates for cellular therapy in transplantation. First clinical results in the field of transplantation should encourage investigators to continue their research to bring MSC therapy to the patient.

Whitesell, L., Kelly, T. E., Saulsbury, F. T., Chance, P. F., and Ochs, H. D. (2001). The immune dysregulation, polyendocrinopathy, enteropathy, Xlinked syndrome (IPEX) is caused by mutations of FOXP3. Nat. Genet. 27, 20-21.

Bestard, O., Cruzado, J. M., Mestre, M., Caldes, A., Bas, J., Carrera, M., Torras, J., Rama, I., Moreso, F., Seron, D., and Grinyo, J. M. (2007). Achieving donor-specific hyporesponsiveness is associated with $\mathrm{FOXP}^{+}$regulatory $\mathrm{T}$ cell recruitment in human renal allograft infiltrates. J. Immunol. 179 , 4901-4909.

Brunstein, C. G., Miller, J. S., Cao, Q., McKenna, D. H., Hippen, K. L. Curtsinger, J., Defor, T., Levine, B. L., June, C. H., Rubinstein, P., McGlave, P. B., Blazar, B. R., and Wagner, J. E. (2011). Infusion of ex vivo expanded $\mathrm{T}$ regulatory cells in adults transplanted with umbilical cord blood: safety profile and detection kinetics. Blood 117, 1061-1070.

Buckner, J. H. (2010). Mechanisms of impaired regulation by CD4(+)CD25(+)FOXP3(+) regulatory $\mathrm{T}$ cells in human autoimmune diseases. Nat. Rev. Immunol. 10, 849-859.

Buron, F., Perrin, H., Malcus, C., Hequet, O., Thaunat, O., KholoppSarda, M. N., Moulin, F. T., and Morelon, E. (2009). Human mesenchymal stem cells and immunosuppressive drug interactions in allogeneic responses: an in vitro study using human cells. Transplant. Proc. 41, 3347-3352.

Carlson, M. J., West, M. L., Coghill, J. M., Panoskaltsis-Mortari, A., Blazar, B. R., and Serody, J. S. (2009).
In vitro-differentiated $\mathrm{TH} 17$ cells mediate lethal acute graft-versushost disease with severe cutaneous and pulmonary pathologic manifestations. Blood 113, 1365-1374.

Casiraghi, F., Azzollini, N., Cassis, P., Imberti, B., Morigi, M., Cugini, D., Cavinato, R. A., Todeschini, M., Solini, S., Sonzogni, A., Perico, N., Remuzzi, G., and Noris, M. (2008). Pretransplant infusion of mesenchymal stem cells prolongs the survival of a semiallogeneic heart transplant through the generation of regulatory T cells. J. Immunol. 181, 3933-3946.

Chen, W., Jin, W., Hardegen, N., Lei, K. J., Li, L., Marinos, N., McGrady, G., and Wahl, S. M. (2003). Conversion of peripheral $\mathrm{CD} 4{ }^{+} \mathrm{CD} 25^{-}$ naive $\mathrm{T}$ cells to $\mathrm{CD} 4{ }^{+} \mathrm{CD} 25^{+}$regulatory $\mathrm{T}$ cells by TGF-beta induction of transcription factor Foxp3. J. Exp. Med. 198, 1875-1886.

Corcione, A., Benvenuto, F., Ferretti, E., Giunti, D., Cappiello, V., Cazzanti, F., Risso, M., Gualandi, F., Mancardi, G. L., Pistoia, V., and Uccelli, A. (2006). Human mesenchymal stem cells modulate B-cell functions. Blood 107, 367-372.

Crop, M. J., Baan, C. C., Korevaar, S. S., Ijzermans, J. N., Pescatori, M., Stubbs, A. P., van Ijcken, W. F., Dahlke, M. H., Eggenhofer, E. Weimar, W., and Hoogduijn, M. J. (2010). Inflammatory conditions affect gene expression and function of human adipose tissue-derived mesenchymal stem cells. Clin. Exp. Immunol. 162, 474-486.

de la Garza-Rodea, A. S., van der Velde-van Dijke, L., Boersma, H., Goncalves, M. A., van Bekkum, D. 
W., de Vries, A. A., and KnaanShanzer, S. (2012). Myogenic properties of human mesenchymal stem cells derived from three different sources. Cell Transplant. 21, 153-173.

Deuse, T., Stubbendorff, M., TangQuan, K., Phillips, N., Kay, M. A., Eiermann, T., Phan, T. T., Volk, H. D., Reichenspurner, H., Robbins, R. C., and Schrepfer, S. (2011). Immunogenicity and immunomodulatory properties of umbilical cord lining mesenchymal stem cells. Cell Transplant. 20, 655-667.

Di Ianni, M., Del Papa, B., De Ioanni, M., Moretti, L., Bonifacio, E., Cecchini, D., Sportoletti, P., Falzetti, F., and Tabilio, A. (2008). Mesenchymal cells recruit and regulate $T$ regulatory cells. Exp. Hematol. 36, 309-318.

Di Ianni, M., Falzetti, F., Carotti, A., Terenzi, A., Castellino, F., Bonifacio, E., Del Papa, B., Zei, T., Ostini, R. I., Cecchini, D., Aloisi, T., Perruccio, K., Ruggeri, L., Balucani, C., Pierini, A., Sportoletti, P., Aristei, C., Falini, B., Reisner, Y., Velardi, A., Aversa, F., and Martelli, M. F. (2011). Tregs prevent GVHD and promote immune reconstitution in HLA-haploidentical transplantation. Blood 117, 3921-3928.

Di Nicola, M., Carlo-Stella, C., Magni, M., Milanesi, M., Longoni, P. D., Matteucci, P., Grisanti, S., and Gianni, A. M. (2002). Human bone marrow stromal cells suppress T-lymphocyte proliferation induced by cellular or nonspecific mitogenic stimuli. Blood 99, 3838-3843.

Dominici, M., Le Blanc, K., Mueller, I., Slaper-Cortenbach, I., Marini, F., Krause, D., Deans, R., Keating, A., Prockop, D., and Horwitz, E. (2006). Minimal criteria for defining multipotent mesenchymal stromal cells. The International Society for Cellular Therapy position statement. Cytotherapy 8, 315-317.

Eggenhofer, E., Renner, P., Soeder, Y., Popp, F. C., Hoogduijn, M. J., Geissler, E. K., Schlitt, H. J., and Dahlke, M. H. (2011). Features of synergism between mesenchymal stem cells and immunosuppressive drugs in a murine heart transplantation model. Transpl. Immunol. 25, 141-147.

Engela, A. U., Baan, C. C., Peeters, A. M., Weimar, W., and Hoogduijn, M. J. (2012). Interaction between adipose-tissue derived mesenchymal stem cells and regulatory T cells. Cell Transplant. doi: 10.3727/096368912X 636984 [Epub ahead of print].

English, K., Barry, F. P., FieldCorbett, C. P., and Mahon, B. P. (2007). IFN-gamma and TNF-alpha differentially regulate immunomodulation by murine mesenchymal stem cells. Immunol. Lett. 110, 91-100.

English, K., Ryan, J. M., Tobin, L., Murphy, M. J., Barry, F. P., and Mahon, B. P. (2009). Cell contact, prostaglandin $\mathrm{E}(2)$ and transforming growth factor beta 1 play non-redundant roles in human mesenchymal stem cell induction of $\mathrm{CD} 4{ }^{+} \mathrm{CD} 25$ (High) forkhead box $\mathrm{P}^{+}$regulatory $\mathrm{T}$ cells. Clin. Exp. Immunol. 156, 149-160.

Fischer, U. M., Harting, M. T., Jimenez, F., Monzon-Posadas, W. O., Xue, H., Savitz, S. I., Laine, G. A., and Cox, C. S. Jr. (2009). Pulmonary passage is a major obstacle for intravenous stem cell delivery: the pulmonary first-pass effect. Stem Cells Dev. 18, 683-692.

Fontenot, J. D., Gavin, M. A., and Rudensky, A. Y. (2003). Foxp3 programs the development and function of $\mathrm{CD}^{+}{ }^{+} \mathrm{CD} 25^{+}$regulatory $\mathrm{T}$ cells. Nat. Immunol. 4, 330-336.

Ford McIntyre, M. S., Young, K. J., Gao, J., Joe, B., and Zhang, L. (2008). Cutting edge: in vivo trogocytosis as a mechanism of double negative regulatory $\mathrm{T}$ cell-mediated antigenspecific suppression. J. Immunol. 181, 2271-2275.

Friedenstein, A. J., Chailakhjan, R. K., and Lalykina, K. S. (1970). The development of fibroblast colonies in monolayer cultures of guinea-pig bone marrow and spleen cells. Cell Tissue Kinet. 3, 393-403.

Fu, S., Zhang, N., Yopp, A. C., Chen, D., Mao, M., Zhang, H., Ding, Y., and Bromberg, J. S. (2004). TGF-beta induces Foxp $3^{+}$T-regulatory cells from $\mathrm{CD} 4{ }^{+} \mathrm{CD} 25^{-}$precursors. Am. J. Transplant. 4, 1614-1627.

Ge, W., Jiang, J., Arp, J., Liu, W., Garcia, B., and Wang, H. (2010). Regulatory T-cell generation and kidney allograft tolerance induced by mesenchymal stem cells associated with indoleamine 2,3-dioxygenase expression. Transplantation 90, 1312-1320.

Ge, W., Jiang, J., Baroja, M. L., Arp, J., Zassoko, R., Liu, W., Bartholomew, A., Garcia, B., and Wang, H. (2009). Infusion of mesenchymal stem cells and rapamycin synergize to attenuate alloimmune responses and promote cardiac allograft tolerance. Am. J. Transplant. 9, 1760-1772.

Ghannam, S., Pene, J., Torcy-Moquet, G., Jorgensen, C., and Yssel, H. (2010). Mesenchymal stem cells inhibit human Th17 cell differentiation and function and induce a T regulatory cell phenotype. J. Immunol. 185, 302-312.

Gondek, D. C., Lu, L. F., Quezada, S. A., Sakaguchi, S., and Noelle, R. J. (2005).
Cutting edge: contact-mediated suppression by $\mathrm{CD}^{+}{ }^{+} \mathrm{CD} 25^{+}$regulatory cells involves a granzyme B-dependent, perforin-independent mechanism. J. Immunol. 174, 1783 1786.

Gonzalez, M. A., Gonzalez-Rey, E., Rico, L., Buscher, D., and Delgado, M. (2009). Adipose-derived mesenchymal stem cells alleviate experimental colitis by inhibiting inflammatory and autoimmune responses. Gastroenterology 136, 978-989.

Gottschalk, R. A., Corse, E., and Allison, J. P. (2012). Expression of Helios in peripherally induced Foxp $3^{+}$regulatory $\mathrm{T}$ cells. J. Immunol. 188, 976-980.

Groh, M. E., Maitra, B., Szekely, E., and Koc, O. N. (2005). Human mesenchymal stem cells require monocytemediated activation to suppress alloreactive T cells. Exp. Hematol. 33, 928-934.

Grossman, W. J., Verbsky, J. W., Tollefsen, B. L., Kemper, C., Atkinson, J. P., and Ley, T. J. (2004). Differential expression of granzymes A and B in human cytotoxic lymphocyte subsets and T regulatory cells. Blood 104 , 2840-2848.

Hayday, A., and Tigelaar, R. (2003). Immunoregulation in the tissues by gammadelta $\mathrm{T}$ cells. Nat. Rev. Immunol. 3, 233-242.

Hendrikx, T. K., van Gurp, E. A., Sewgobind, V. D., Mol, W. M., Schoordijk W., Klepper, M., Velthuis, J. H., Geel, A., Ijzermans, J. N., Weimar, W., and Baan, C. C. (2009a). Generation of donor-specific regulatory $\mathrm{T}$-cell function in kidney transplant patients. Transplantation 87, 376-383.

Hendrikx, T. K., Velthuis, J. H., Klepper, M., van Gurp, E., Geel, A., Schoordijk, W., Baan, C. C., and Weimar, W. (2009b). Monotherapy rapamycin allows an increase of CD4 CD25 FoxP3 $\mathrm{T}$ cells in renal recipients. Transpl. Int. 22, 884-891.

Hoogduijn, M. J., Crop, M. J., Korevaar, S. S., Peeters, A. M., Eijken, M. Maat, L. P., Balk, A. H., Weimar, W. and Baan, C. C. (2008). Susceptibility of human mesenchymal stem cells to tacrolimus, mycophenolic acid, and rapamycin. Transplantation 86, 1283-1291.

Hoogduijn, M. J., Crop, M. J., Peeters, A. M., Van Osch, G. J., Balk, A. H., Ijzermans, J. N., Weimar, W., and Baan, C. C. (2007). Human heart, spleen, and perirenal fat-derived mesenchymal stem cells have immunomodulatory capacities. Stem Cells Dev. 16, 597-604.

Hoogduijn, M. J., Eggenhofer, E., Popp, F. C., Renner, P., Weimar,
W., Baan, C. C., and Dahlke, M. H. (2011). Living mesenchymal stem cells disappear rapidly after intravenous infusion. Cytotherapy 13(Annual Meeting Abstract Supplement), abstract number 57 .

Hoogduijn, M. J., Popp, F., Verbeek, R., Masoodi, M., Nicolaou, A., Baan, C., and Dahlke, M. H. (2010a). The immunomodulatory properties of mesenchymal stem cells and their use for immunotherapy. Int. Immunopharmacol. 10, 1496-1500.

Hoogduijn, M. J., Popp, F. C., Grohnert, A., Crop, M. J., van Rhijn, M., Rowshani, A. T., Eggenhofer, E., Renner, P., Reinders, M. E., Rabelink, T. J., van der Laan, L. J., Dor, F. J., Ijzermans, J. N., Genever, P. G., Lange, C., Durrbach, A., Houtgraaf, J. H., Christ, B., Seifert, M., Shagidulin, M., Donckier, V., Deans, R., Ringden, O., Perico, N., Remuzzi, G., Bartholomew, A., Schlitt, H. J., Weimar, W., Baan, C. C., Dahlke, M. H., and MISOT Study Group. (2010b). Advancement of mesenchymal stem cell therapy in solid organ transplantation (MISOT). Transplantation 90, 124-126.

Issa, F., Hester, J., Goto, R., Nadig, S. N., Goodacre, T. E., and Wood, K. (2010). Ex vivo-expanded human regulatory $\mathrm{T}$ cells prevent the rejection of skin allografts in a humanized mouse model. Transplantation 90, 1321-1327.

Jiang, X. X., Zhang, Y., Liu, B., Zhang, S. X., Wu, Y., Yu, X. D., and Mao, N. (2005). Human mesenchymal stem cells inhibit differentiation and function of monocyte-derived dendritic cells. Blood 105, 4120-4126.

Jurgens, B., Hainz, U., Fuchs, D., Felzmann, T., and Heitger, A. (2009). Interferon-gamma-triggered indoleamine 2,3-dioxygenase competence in human monocyte-derived dendritic cells induces regulatory activity in allogeneic $\mathrm{T}$ cells. Blood 114, 3235-3243.

Kappel, L. W., Goldberg, G. L., King, C. G., Suh, D. Y., Smith, O. M., Ligh, C., Holland, A. M., Grubin, J., Mark, N. M., Liu, C., Iwakura, Y., Heller, G., and van den Brink, M. R. (2009). IL-17 contributes to CD4-mediated graft-versus-host disease. Blood 113 , 945-952.

Kavanagh, H., and Mahon, B. P. (2011). Allogeneic mesenchymal stem cells prevent allergic airway inflammation by inducing murine regulatory $\mathrm{T}$ cells. Allergy 66, 523-531.

Kobayashi, I., Shiari, R., Yamada, M., Kawamura, N., Okano, M., Yara, A., Iguchi, A., Ishikawa, N., Ariga, T., Sakiyama, Y., Ochs, H. D., and 
Kobayashi, K. (2001). Novel mutations of FOXP3 in two Japanese patients with immune dysregulation, polyendocrinopathy, enteropathy, $\mathrm{X}$ linked syndrome (IPEX). J. Med. Genet. 38, 874-876.

Kraitchman, D. L., Tatsumi, M., Gilson, W. D., Ishimori, T., Kedziorek, D., Walczak, P., Segars, W. P., Chen, H. H., Fritzges, D., Izbudak, I., Young, R. G., Marcelino, M., Pittenger, M. F., Solaiyappan, M., Boston, R. C., Tsui, B. M., Wahl, R. L., and Bulte, J. W. (2005). Dynamic imaging of allogeneic mesenchymal stem cells trafficking to myocardial infarction. Circulation 112, 1451-1461.

Le Blanc, K., Frassoni, F., Ball, L., Locatelli, F., Roelofs, H., Lewis, I., Lanino, E., Sundberg, B., Bernardo, M. E., Remberger, M., Dini, G., Egeler, R. M., Bacigalupo, A., Fibbe, W., Ringden, O., and Developmental Committee of the European Group for Blood and Marrow Transplantation. (2008). Mesenchymal stem cells for treatment of steroid-resistant, severe, acute graft-versus-host disease: a phase II study. Lancet 371, 1579-1586.

Le Blanc, K., Rasmusson, I., Sundberg, B., Gotherstrom, C., Hassan, M., Uzunel, M., and Ringden, O. (2004). Treatment of severe acute graft-versus-host disease with third party haploidentical mesenchymal stem cells. Lancet 363, 14391441.

Liu, W., Putnam, A. L., Xu-Yu, Z., Szot, G. L., Lee, M. R., Zhu, S., Gottlieb, P. A., Kapranov, P., Gingeras, T. R., Fazekas de St Groth, B., Clayberger, C., Soper, D. M., Ziegler, S. F., and Bluestone, J. A. (2006). CD127 expression inversely correlates with FoxP3 and suppressive function of human $\mathrm{CD} 4^{+}$Treg cells. J. Exp. Med. 203, 1701-1711.

Ma, A., Qi, S., Song, L., Hu, Y., Dun, H., Massicotte, E., Dupuis, M., Daloze, P., and Chen, H. (2011). Adoptive transfer of $\mathrm{CD} 4^{+} \mathrm{CD} 25^{+}$ regulatory cells combined with lowdose sirolimus and anti-thymocyte globulin delays acute rejection of renal allografts in Cynomolgus monkeys. Int. Immunopharmacol. 11, 618-629.

Maccario, R., Podesta, M., Moretta, A., Cometa, A., Comoli, P., Montagna, D., Daudt, L., Ibatici, A., Piaggio, G., Pozzi, S., Frassoni, F., and Locatelli, F. (2005). Interaction of human mesenchymal stem cells with cells involved in alloantigen-specific immune response favors the differentiation of $\mathrm{CD}^{+}$T-cell subsets expressing a regulatory/suppressive phenotype. Haematologica 90, 516525.

McHugh, R. S., Whitters, M. J., Piccirillo, C. A., Young, D. A., Shevach, E. M., Collins, M., and Byrne, M. C. (2002). CD4(+)CD25(+) immunoregulatory $\mathrm{T}$ cells: gene expression analysis reveals a functional role for the glucocorticoidinduced TNF receptor. Immunity 16 , 311-323.

McMurchy, A. N., Bushell, A., Levings, M. K., and Wood, K. J. (2011). Moving to tolerance: clinical application of T regulatory cells. Semin. Immunol. 23, 304-313.

Meisel, R., Zibert, A., Laryea, M., Gobel, U., Daubener, W., and Dilloo, D. (2004). Human bone marrow stromal cells inhibit allogeneic T-cell responses by indoleamine 2,3dioxygenase-mediated tryptophan degradation. Blood 103, 4619-4621.

Monteiro, M., Almeida, C. F., Caridade, M., Ribot, J. C., Duarte, J., AguaDoce, A., Wollenberg, I., Silva-Santos, B., and Graca, L. (2010). Identification of regulatory Foxp $3^{+}$invariant NKT cells induced by TGF-beta. $J$. Immunol. 185, 2157-2163.

Nadig, S. N., Wieckiewicz, J., Wu, D. C., Warnecke, G., Zhang, W., Luo, S., Schiopu, A., Taggart, D. P., and Wood, K. J. (2010). In vivo prevention of transplant arteriosclerosis by ex vivo-expanded human regulatory T cells. Nat. Med. 16, 809-813.

Nasef, A., Mathieu, N., Chapel, A., Frick, J., Francois, S., Mazurier, C., Boutarfa, A., Bouchet, S., Gorin, N. C., Thierry, D., and Fouillard, L. (2007). Immunosuppressive effects of mesenchymal stem cells: involvement of HLA-G. Transplantation 84, 231-237.

Nauta, A. J., Kruisselbrink, A. B., Lurvink, E., Willemze, R., and Fibbe, W. E. (2006). Mesenchymal stem cells inhibit generation and function of both $\mathrm{CD} 34^{+}$-derived and monocytederived dendritic cells. J. Immunol. 177, 2080-2087.

Nemeth, K., Leelahavanichkul, A., Yuen, P. S., Mayer, B., Parmelee, A., Doi, K., Robey, P. G., Leelahavanichkul, K., Koller, B. H., Brown, J. M., Hu, X., Jelinek, I., Star, R. A., and Mezey, E. (2009). Bone marrow stromal cells attenuate sepsis via prostaglandin E(2)-dependent reprogramming of host macrophages to increase their interleukin-10 production. Nat. Med. 15, 42-49.

Perico, N., Casiraghi, F., Introna, M., Gotti, E., Todeschini, M., Cavinato, R. A., Capelli, C., Rambaldi, A., Cassis, P., Rizzo, P., Cortinovis, M., Marasa, M., Golay, J., Noris, M., and Remuzzi,
G. (2011). Autologous mesenchymal stromal cells and kidney transplantation: a pilot study of safety and clinical feasibility. Clin. J. Am. Soc. Nephrol. 6, 412-422.

Pittenger, M. F., Mackay, A. M., Beck, S. C., Jaiswal, R. K., Douglas, R., Mosca, J. D., Moorman, M. A., Simonetti, D. W., Craig, S., and Marshak, D. R. (1999). Multilineage potential of adult human mesenchymal stem cells. Science 284, 143-147.

Popp, F. C., Eggenhofer, E., Renner, P., Slowik, P., Lang, S. A., Kaspar, H., Geissler, E. K., Piso, P., Schlitt, H. J., and Dahlke, M. H. (2008). Mesenchymal stem cells can induce long-term acceptance of solid organ allografts in synergy with low-dose mycophenolate. Transpl. Immunol. 20, 55-60.

Prevosto, C., Zancolli, M., Canevali, P., Zocchi, M. R., and Poggi, A. (2007). Generation of $\mathrm{CD}^{+}{ }^{+}$or $\mathrm{CD}_{8}{ }^{+}$regulatory $\mathrm{T}$ cells upon mesenchymal stem cell-lymphocyte interaction. Haematologica 92, 881-888.

Raffaghello, L., Bianchi, G., Bertolotto, M., Montecucco, F., Busca, A., Dallegri, F., Ottonello, L., and Pistoia, V. (2008). Human mesenchymal stem cells inhibit neutrophil apoptosis: a model for neutrophil preservation in the bone marrow niche. Stem Cells 26 , 151-162.

Read, S., Malmstrom, V., and Powrie, F. (2000). Cytotoxic T lymphocyteassociated antigen 4 plays an essential role in the function of $\mathrm{CD} 25(+) \mathrm{CD} 4(+)$ regulatory cells that control intestinal inflammation. J. Exp. Med. 192, 295-302.

Reibke, R., Garbi, N., Ganss, R., Hammerling, G. J., Arnold, B., and Oelert, T. (2006). $\mathrm{CD}^{+}$regulatory $\mathrm{T}$ cells generated by neonatal recognition of peripheral self-antigen. Proc. Natl. Acad. Sci. U.S.A. 103, 15142-15147.

Roncarolo, M. G., Gregori, S., Battaglia, M., Bacchetta, R., Fleischhauer, K., and Levings, M. K. (2006). Interleukin-10-secreting type 1 regulatory $\mathrm{T}$ cells in rodents and humans. Immunol. Rev. 212, 28-50.

Ryan, J. M., Barry, F., Murphy, J. M., and Mahon, B. P. (2007). Interferongamma does not break, but promotes the immunosuppressive capacity of adult human mesenchymal stem cells. Clin. Exp. Immunol. 149, 353363.

Sakaguchi, S., Sakaguchi, N., Asano, M., Itoh, M., and Toda, M. (1995). Immunologic self-tolerance maintained by activated $\mathrm{T}$ cells expressing IL-2 receptor alpha-chains (CD25). Breakdown of a single mechanism of self-tolerance causes various autoimmune diseases. J. Immunol. 155, 1151-1164.

Salomon, B., Lenschow, D. J., Rhee, L., Ashourian, N., Singh, B., Sharpe, A., and Bluestone, J. A. (2000). B7/CD28 costimulation is essential for the homeostasis of the $\mathrm{CD} 4{ }^{+} \mathrm{CD} 25^{+}$ immunoregulatory $\mathrm{T}$ cells that control autoimmune diabetes. Immunity $12,431-440$.

Sato, K., Ozaki, K., Oh, I., Meguro, A., Hatanaka, K., Nagai, T., Muroi, K., and Ozawa, K. (2007). Nitric oxide plays a critical role in suppression of T-cell proliferation by mesenchymal stem cells. Blood 109, 228-234.

Schliesser, U., Streitz, M., and Sawitzki, B. (2012). Tregs: application for solid-organ transplantation. Curr. Opin. Organ Transplant. 17, 34-41.

Seddiki, N., Santner-Nanan, B., Martinson, J., Zaunders, J., Sasson, S., Landay, A., Solomon, M., Selby, W. Alexander, S. I., Nanan, R., Kelleher, A., and Fazekas de St Groth B. (2006). Expression of interleukin (IL)-2 and IL-7 receptors discriminates between human regulatory and activated T cells. J. Exp. Med. 203, 1693-1700.

Selmani, Z., Naji, A., Zidi, I., Favier, B., Gaiffe, E., Obert, L., Borg C., Saas, P., Tiberghien, P., RouasFreiss, N., Carosella, E. D., and Deschaseaux, F. (2008). Human leukocyte antigen-G5 secretion by human mesenchymal stem cells is required to suppress $\mathrm{T}$ lymphocyte and natural killer function and to induce $\mathrm{CD}^{+} \mathrm{CD} 25$ highFOXP3 ${ }^{+}$ regulatory $\mathrm{T}$ cells. Stem Cells 26, 212-222.

Shi, X. L., Gu, J. Y., Han, B., Xu, H. Y., Fang, L., and Ding, Y. T. (2010). Magnetically labeled mesenchymal stem cells after autologous transplantation into acutely injured liver. World $J$. Gastroenterol. 16, 3674-3679.

Shimizu, J., Yamazaki, S., Takahashi, T., Ishida, Y., and Sakaguchi, S. (2002). Stimulation of CD25(+) $\mathrm{CD} 4(+)$ regulatory $\mathrm{T}$ cells through GITR breaks immunological selftolerance. Nat. Immunol. 3, 135-142.

Shin, H. J., Baker, J., Leveson-Gower, D. B., Smith, A. T., Sega, E. I., and Negrin, R. S. (2011). Rapamycin and IL-2 reduce lethal acute graftversus-host disease associated with increased expansion of donor type $\mathrm{CD}^{+}{ }^{+} \mathrm{CD} 25^{+}$Foxp $^{+}$regulatory $\mathrm{T}$ cells. Blood 118, 2342-2350.

Sotiropoulou, P. A., Perez, S. A., Gritzapis, A. D., Baxevanis, C. N., and Papamichail, M. (2006). Interactions between human mesenchymal stem cells and natural killer cells. Stem Cells 24, 74-85. 
Spaggiari, G. M., Abdelrazik, H., Becchetti, F., and Moretta, L. (2009). MSCs inhibit monocyte-derived DC maturation and function by selectively interfering with the generation of immature DCs: central role of MSC-derived prostaglandin E2. Blood 113, 6576-6583.

Takahashi, T., Tagami, T., Yamazaki, S., Uede, T., Shimizu, J., Sakaguchi, N., Mak, T. W., and Sakaguchi, S. (2000). Immunologic self-tolerance maintained by $\mathrm{CD} 25(+) \mathrm{CD} 4(+)$ regulatory $\mathrm{T}$ cells constitutively expressing cytotoxic $\mathrm{T}$ lymphocyte-associated antigen 4. J. Exp. Med. 192, 303-310.

Tang, Q., and Bluestone, J. A. (2008). The Foxp $3^{+}$regulatory $\mathrm{T}$ cell: a jack of all trades, master of regulation. Nat. Immunol. 9, 239-244.

Tatara, R., Ozaki, K., Kikuchi, Y., Hatanaka, K., Oh, I., Meguro, A., Matsu, H., Sato, K., and Ozawa, K. (2011). Mesenchymal stromal cells inhibit Th17 but not regulatory Tcell differentiation. Cytotherapy 13, 686-694.

Thornton, A. M., Korty, P. E., Tran, D. Q., Wohlfert, E. A.,
Murray, P. E., Belkaid, Y., and Shevach, E. M. (2010). Expression of Helios, an Ikaros transcription factor family member, differentiates thymic-derived from peripherally induced Foxp $3^{+} \mathrm{T}$ regulatory cells. J. Immunol. 184, 3433-3441.

Trzonkowski, P., Bieniaszewska, M., Juscinska, J., Dobyszuk, A., Krzystyniak, A., Marek, N., Mysliwska, J., and Hellmann, A. (2009). First-in-man clinical results of the treatment of patients with graft versus host disease with human ex vivo expanded $\mathrm{CD} 4^{+} \mathrm{CD} 25^{+} \mathrm{CD} 127^{-} \mathrm{T}$ regulatory cells. Clin. Immunol. 133, 22-26.

Velthuis, J. H., Mol, W. M., Weimar, W., and Baan, C. C. (2006). $\mathrm{CD}^{+}{ }^{+} \mathrm{CD} 25$ bright $^{+}$regulatory $\mathrm{T}$ cells can mediate donor nonreactivity in long-term immunosuppressed kidney allograft patients. Am. J. Transplant. 6, 2955-2964.

Weiner, H. L. (2001). The mucosal milieu creates tolerogenic dendritic cells and $\mathrm{T}(\mathrm{R}) 1$ and $\mathrm{T}(\mathrm{H}) 3$ regulatory cells. Nat. Immunol. 2, 671-672.

Wieczorek, G., Asemissen, A., Model, F., Turbachova, I., Floess, S., Liebenberg, V., Baron, U., Stauch, D., Kotsch,
K., Pratschke, J., Hamann, A., Loddenkemper, C., Stein, H., Volk, H. D., Hoffmuller, U., Grutzkau, A., Mustea, A., Huehn, J., Scheibenbogen, C., and Olek, S. (2009). Quantitative DNA methylation analysis of FOXP3 as a new method for counting regulatory $\mathrm{T}$ cells in peripheral blood and solid tissue. Cancer Res. 69, 599-608.

Ziegler, S. F. (2006). FOXP3: of mice and men. Аnnu. Rev. Immunol. 24, 209-226.

Zonta, S., De Martino, M., Bedino, G., Piotti, G., Rampino, T., Gregorini, M., Frassoni, F., Dal Canton, A., Dionigi, P., and Alessiani, M. (2010). Which is the most suitable and effective route of administration for mesenchymal stem cellbased immunomodulation therapy in experimental kidney transplantation: endovenous or arterial? Transplant. Proc. 42, 1336-1340.

Zuk, P. A., Zhu, M., Ashjian, P., De Ugarte, D. A., Huang, J. I., Mizuno, H., Alfonso, Z. C., Fraser, J. K., Benhaim, P., and Hedrick, M. H. (2002). Human adipose tissue is a source of multipotent stem cells. Mol. Biol. Cell 13, 4279-4295.
Conflict of Interest Statement: The authors declare that the research was conducted in the absence of any commercial or financial relationships that could be construed as a potential conflict of interest.

Received: 03 April 2012; paper pending published: 25 April 2012; accepted: 03 May 2012; published online: 18 May 2012.

Citation: Engela $A U$, Baan CC, Dor FJMF, Weimar $W$ and Hoogduijn MJ (2012) On the interactions between mesenchymal stem cells and regulatory $T$ cells for immunomodulation in transplantation. Front. Immun. 3:126. doi: 10.3389/fimmu.2012.00126

This article was submitted to Frontiers in Alloimmunity and Transplantation, a specialty of Frontiers in Immunology. Copyright () 2012 Engela, Baan, Dor, Weimar and Hoogduijn. This is an openaccess article distributed under the terms of the Creative Commons Attribution Non Commercial License, which permits non-commercial use, distribution, and reproduction in other forums, provided the original authors and source are credited. 